\title{
Electromagnetic Analysis of Organic Waste and Blust Furnace Slag Mixtures
}

\author{
Mustafa Kaan Baltacıoğlu ${ }^{* *}(\mathbb{D})$, Mustafa Tunahan Başar ${ }^{2}(\mathbb{D})$, Muharrem Karaaslan ${ }^{3}(\mathbb{D}$, \\ Fatih Özkan Alkurt ${ }^{3}{ }^{(}$, Samet Alparslan Arıpek ${ }^{4}$ (b)
}

\author{
"4iskenderun Technical University, Engineering and Natural Sciences Faculty, Mechatronics Engineering Dep., Turkey \\ ${ }^{2}$ iskenderun Technical University, Engineering and Natural Sciences Faculty, Mechanical Engineering Dep., Turkey \\ ${ }^{3}$ Iskenderun Technical University, Engineering and Natural Sciences Faculty, Electrical Electronical Engineering Dep., Turkey
}

\begin{abstract}
In this experimental study, a composite structure was obtained by combining apple pulp wastes with slag wastes. Electromagnetic field characteristics of test samples have been determined. In the scope of the study, dry apple pulp and slag wastes were transformed into square plate form using a specially designed mold and a pressing bench with a capacity of 50 tons. The measurements were carried out in the 3-18 GHz frequency band in the microwave laboratory. In the measurements, five different measurement results were obtained: air, high quality commercial absorber, pure apple pulp, $50 \mathrm{~g}$ apple pulp with slag and $150 \mathrm{~g}$ of slag added apple pulp. The results of the measured samples were compared and interpreted with the results of air and high quality commercial absorber material. As a result, the samples formed by pure apple pulp, $50 \mathrm{~g}$ slag-added sample and $150 \mathrm{~g}$ slagadded sample in terms of electromagnetic permeability similar results were obtained. The slag-added sample of $50 \mathrm{~g}$ performed better absorption in certain frequency regions than the slag-added sample of $150 \mathrm{~g}$. In addition, it produces close transmission values in three samples in the 8-12 GHz X-band frequency range. In addition, considering the absorption values of the slag-added structures, it was determined that they absorb signals $90 \%$ on average in the frequency regions of $8 \mathrm{GHz}$ and above.
\end{abstract}

Keywords: Organic waste, blast furnace slag, absorber, electromagnetic conductivity.

\section{INTRODUCTION}

Due to the increasing consumption trend with the developing technology, environmental pollution and dramatic waste formation occur on a global scale. This situation poses a great threat to the environment and human health [1]. On the other hand, considering the limited raw material resources and the increase in raw material needs, the idea of meeting the raw material need from waste arises [2].

Waste recovery is very important for economic sustainability. Therefore, developed and developing countries tend to work on the recovery and efficient use of waste [3]. Waste can be classified according to many parameters such as economic values, amount of formation, recovery conditions. However, they are classified as waste, organic waste, metal waste, plastic waste, electronic waste, paper-cardboard waste according to the amount of formation. When evaluated to its formation, most waste generation is observed in organic waste [4].
Increased waste generation for waste recovery is also associated with increased energy demand. Converting waste to energy has great advantages in terms of economic conditions and environment. Therefore, encouraging decisions have been taken in various countries around the world to provide energy recovery from waste [5-7]. The Government of India has seen agricultural waste as a significant income potential. In this context, studies have shown that farmers gain high income from biogas production and worm fertilization [8]. On the other hand, considering the dependence on fossil fuels, the fact that fossil fuels are exhaustible and pose an environmental threat reveals results that support the idea of using organic wastes as energy and raw materials [9-10]. If organic wastes are not utilized, their storage poses a problem. In addition, during traditional disposal methods, problems such as the inadequacy of the lands, the emission of greenhouse gases and the spread of harmful substances to the environment arise [11-13]. When organic wastes are integrated into recovery, it is possible to gain energy and raw materials. Organic wastes can be used as an energy source, 
especially in obtaining biogas and using it in electricity generation [14-16].

Organic wastes, which are generally used for energy production, can also be used as a raw material source. In some studies, it is seen that it is appropriate to use agricultural wastes in animal feed production [17]. In another study conducted for the evaluation of food wastes, the chemical properties of some food wastes were examined. These wastes found that they have the potential to be reused in the production of products such as drugs and food supplements [18]. In a study conducted on the determination of some mechanical properties of organic wastes, the electromagnetic field and thermal properties of pomegranate seed wastes were tried to be determined and it was mentioned that these wastes could be added as additives to the compositions of thermal insulation, electromagnetic absorber, etc. [19-20]. In addition, absorber and radome applications have an important place in electromagnetic field applications [21].

In this study, it was tried to determine the electromagnetic field properties of the sample obtained by steel powder (slag) wastes used in the iron and steel industry with organic wastes. Within the scope of the study, the experimental results of pure apple pulp and slag-added apple pulp were examined in detail. The comparisons of both samples in terms of cutting or not affecting the signals on the electromagnetic field permeability are presented by graphical analysis.

\section{MATERIALS AND METHODS}

In this study, apple pulp wastes and metal wastes (slag) were selected as samples in experimental studies. First of all, the algorithm that enables organic wastes to be converted to sample format is shown in Figure 2.1. The waste product to be recycled is determined from organic wastes with a wide product potential. In the ongoing process, the determined waste product must be separated into structures such as water, shell and pulp. Decomposed waste structures are subjected to dehumidification and dried in the oven in order to prevent decay. Then, in order to determine the electromagnetic properties of the samples, the test samples are made ready by a press bench with a capacity of 50 tons and a specially produced square plate production mold.

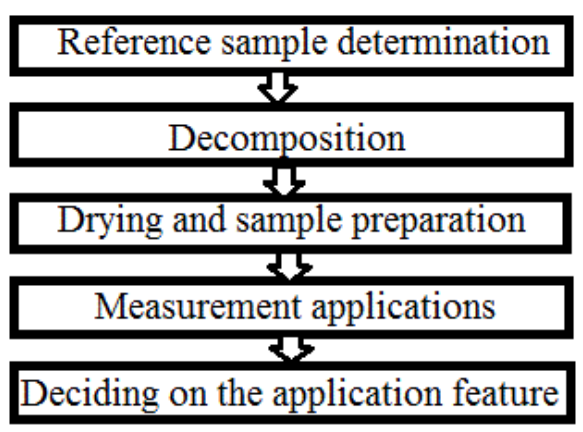

Figure 2.1. Wastw recovery agorithm

The slag used in the study was purchased from İskenderun Demir ve Çelik Company and its specific gravity is $2.89 \mathrm{~g}$
/ cm3 and Blaine fineness is $540 \mathrm{~m} 2$ / kg. In addition, the chemical properties of the slag are shown in Table 2.1.

Table 2.1. Chemical properties of blast furnace slag [22].

\begin{tabular}{|c|c|}
\hline Chemical composition & Analysis results of slag (\%) \\
\hline $\mathrm{CaO}$ & 36.25 \\
\hline $\mathrm{SiO}_{2}$ & $34-36$ \\
\hline $\mathrm{SO}_{3}$ & 0.60 \\
\hline $\mathrm{Na}_{2} \mathrm{O}$ & 0.28 \\
\hline $\mathrm{K}_{2} \mathrm{O}$ & 0.75 \\
\hline $\mathrm{S}^{-2}$ & 0.51 \\
\hline $\mathrm{Al}_{2} \mathrm{O}_{3}$ & 11.34 \\
\hline $\mathrm{Fe}_{2} \mathrm{O}_{3}$ & 0.74 \\
\hline $\mathrm{MgO}$ & 6.10 \\
\hline Loss of glow & 0 \\
\hline Free Lime & 0 \\
\hline
\end{tabular}

The drying oven shown in Figure 2.2 is an oven with a capacity of $300^{\circ} \mathrm{C}$, powered by electricity and generating heat with the resistances inside. The waste samples laid on metal plates are dehumidified for 4 hours at $82{ }^{\circ} \mathrm{C}$ in this oven and converted into a form suitable for pressing.

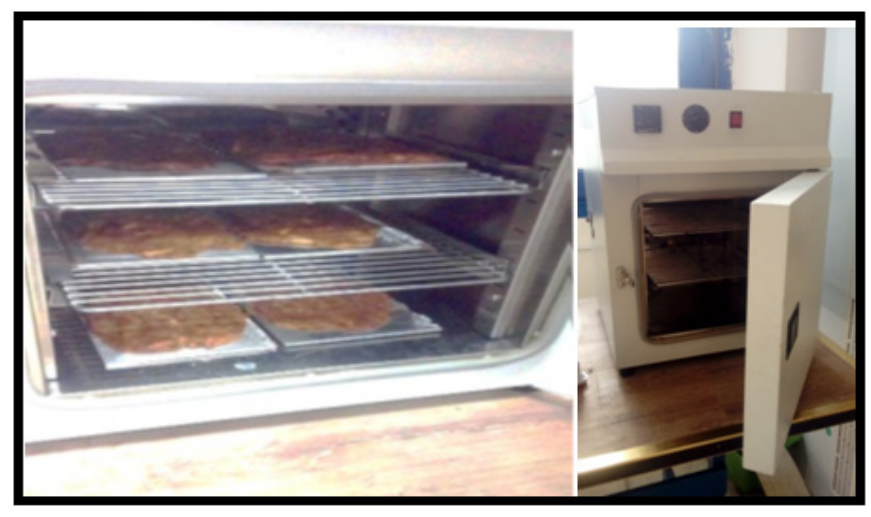

Figure 2.2. Drying oven

The dried organic waste samples and slag wastes are converted into sample format with a specially designed mold and pressing bench.

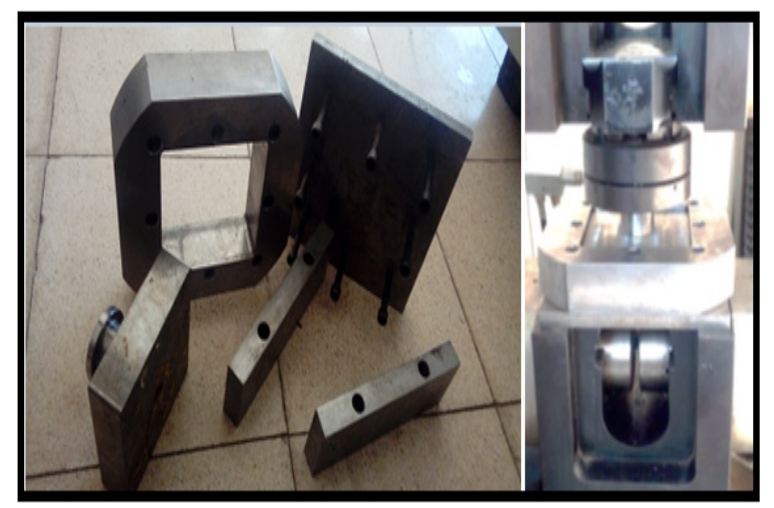

Figure 2.3. Square Plate Production Mold Parts

As shown in Figure 2.3 the mold pressing block, designed to produce samples with a surface area of $16 \times 16 \mathrm{~cm}^{2}$ and a thickness of $5 \mathrm{~mm}-50 \mathrm{~mm}$, consists of a total of four main elements: lower table, female mold and sample extraction legs. Here, the thrust block is made of 1050 steel and is resistant to high pressures. The mold cavity is worked with 10${ }^{3} \mathrm{~cm}$ measurement accuracy. The lower table is the part on 
which the sample is pressed and it is made of st- 37 steel. The female mold serves as the filling chamber of the sample and is the most important part of the mold. This part is made of 2040 manufacturing steels and the working gap is designed with $10-^{3} \mathrm{~cm}$ precision.

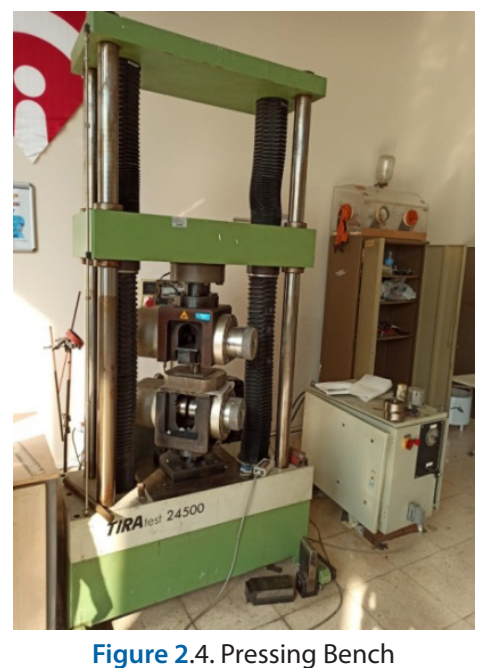

The pressing bench shown in Figure 2.4 is a bench with a maximum capacity of 50 tons and can be operated manually. A specially produced mold is placed between the upper and lower jaws seen on the counter. After the mold cavity and compression blocks are fixed, pressing at the desired value can be applied to the sample in the mold cavity through the control screen of the device. With the help of the screen on the pressing machine unit, the applied pressure value is observed and can be adjusted to the desired values instantly.

Two-port Agilent N5234A PNA-L Microwave Network Analyzer was used to determine the properties of the prepared samples.

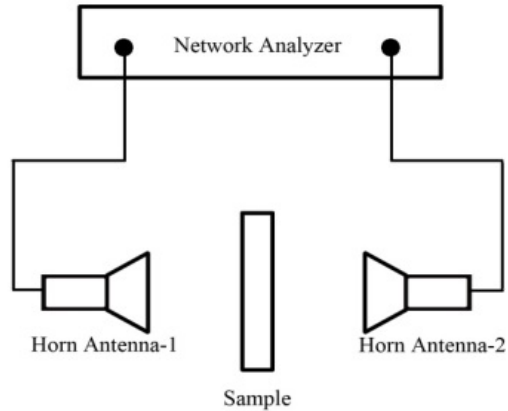

Figure 2.5. Schematic view of Agilent N5234A PNA-L Microwave Network Analyzer

The schematic view of the test setup established to determine the electromagnetic behavior of the samples is as shown in Figure 2.5. Testing is carried out by placing samples at the midpoint of two broadband linearly polarized horn antennas. Network analyzer is used to measure the parameters S11, S12, S21 and S22 for a two-port system called scatter parameters (S-parameters). Here, S11 and S22 represent the amount of power reflected back from the first and second ports, respectively, while the parameters S12 and S21 show the power transferred between the two ports. As a result, the parameters S11 and S22 selected as reflection parameters are equal to each other, and in the same way, the parameters S12 and S21, which are evaluated as transmission parameters, are equal to each other.

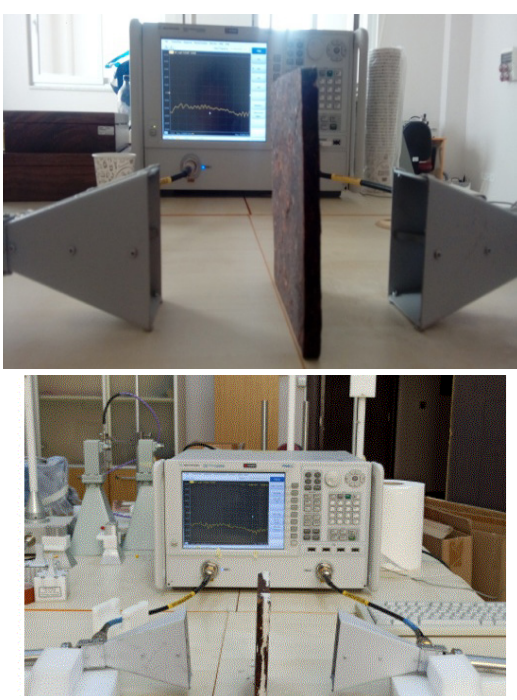

Figure 2.6. Electromagnetic test setup and test application

While performing the measurements, firstly, the calibration process of the device is performed in three conditions, open, closed and short circuit. Then the measurement for air is taken as a reference. Finally, produced samples are subjected to the measurement process as seen in Figure 2.6. The samples are made by placing the samples vertically between two antennas at a distance of $10 \mathrm{~cm}$ from each antenna.

\section{RESULTS AND DISCUSSION}

In this section, reflection and transmission values of samples prepared by experimental studies in the microwave laboratory have been obtained. As is known, empty air environments do not affect electromagnetic signals in terms of reflection or transmission parameters. Therefore, the air environment reflection and transmission parameters were determined in the device first, and other measurements were interpreted according to the air reference. In addition, measurement results were obtained for a professional absorber material currently in use, and electromagnetic characteristics were obtained for pure apple, $50 \mathrm{~g}$ slag-added sample and $150 \mathrm{~g}$ slag-added sample according to their close behavior to air and absorber material.

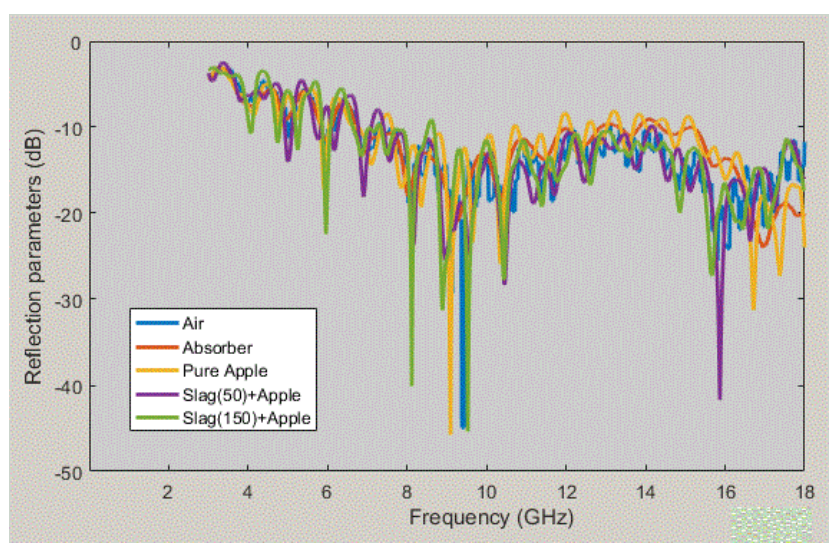

Figure 3.1. Reflection parameters of samples after electromagnetic field test 
The reflection values obtained with five different setups are as shown in Figure 3.1. These five different mechanisms are described in the following order;

- Air

- Electromagnetic absorber

- pure apple sample

- 50gr Slag and Apple combination

- 150gr Slag and Apple combination

Here, when the reflection values are compared with air, the retro reflection values of the combinations of slag and apple samples occur in a multi-band fashion, which supports the idea that the signals are not reflected back.

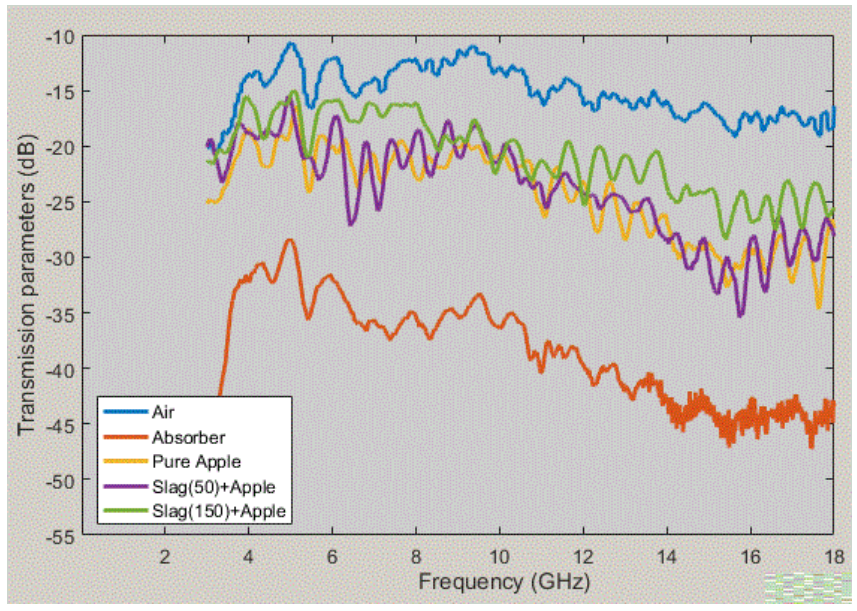

Figure 3.2. Transmission parameters of samples after electromagnetic field tests

Transmission values between two antennas have been measured with five different setups and are given in Figure 4.2. As shown in Figure 4.2, compared to air, the combination of apple and slag-apple structures reduce the transmission value in the 3-18 GHz range. The structure using 50gr slag in the 6-8 GHz and 13-16 GHz bands reduces the transmission value by approximately $10 \mathrm{~dB}$ compared to the structure using 150 gr slag. Remarkably, when the slag addition is increased, the transmission values decrease. In addition, when the frequency range of 8-12 GHz is examined in transmission parameters, it is seen that transmission losses at the

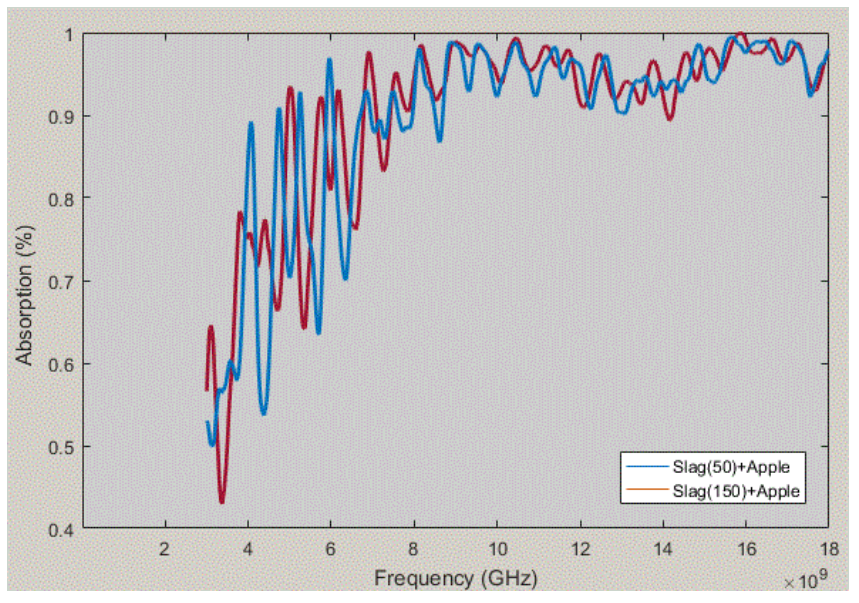

Figure 3.3. Signal absorption characteristic of $50 \mathrm{~g}$ slag-added sample and $150 \mathrm{~g}$ slag-added sample same levels are observed in pure apple, 50 g slag-added apple and $150 \mathrm{~g}$ slag-added apple structures. In this case, it was determined that the slag addition does not provide great advantages to the pure apple pulp structure in terms of electromagnetic permeability in some frequency regions.

S11 (reflection values) and S12 (transmission values obtained as a result of electromagnetic field tests can be calculated with the help of the formula shown in Eq.1 for each sample.

$$
\text { Absorption }=1-\left(|\mathrm{S} 11|^{2}\right)-\left(|\mathrm{S} 12|^{2}\right)
$$

The reflection and transmission values obtained by using the absorption equation were converted from decibels to linear. The graph given in Figure 4.3 gives the electromagnetic signal absorption characteristic of both slag combinations. The developed samples perform excellent signal absorption in the $10.25 \mathrm{GHz}$ and $15.8 \mathrm{GHz}$ frequency regions. In addition, there is an average of $90 \%$ signal absorption in the $8-17 \mathrm{GHz}$ range.

In the light of the results obtained, it is predicted that the proposed sample can be used in communication systems such as radar. In addition, these frequency regions have a wide range of applications.

\section{CONCLUSION}

In general, millions of tons of waste derivatives are dysfunctional worldwide and pose problems for the environment and public health. In this study, by approaching waste recovery with an innovative perspective, a new structure was obtained by combining apple pulp, an organic waste, and slag samples with metal waste, and the electromagnetic absorption characteristic of this samples was examined in detail. In this context, it has been proved that it is possible to develop absorber materials that are economically used in high value-added technologies in the study conducted on recycling waste.

With the samples proposed in the study, it has been shown that it is possible to obtain absorption with high efficiency, especially in high frequency regions. Considering the general findings, it has been determined that studies on the physical combination of slag wastes and apple pulp wastes need to be deepened and the results change negatively when a certain amount of slag additions are exceeded in terms of electromagnetic field permeability. Ensuring improvements in combining two waste structures with each other during the sample preparation process and determining the optimum slag amount in a more convergent result between these two reference measurements can be a source for future studies.

\section{RERERENCES}

[1] Karak, T., Bhagat, R. M., \& Bhattacharyya, P. (2012). Municipal solid waste generation, composition, and management: the world scenario. Critical Reviews in Environmental Science and Technology, 42(15), 1509-1630. DOI: https://doi.org/10.1080/10643389.201 1.569871 
[2] Giugliano, M., Cernuschi, S., Grosso, M., \& Rigamonti, L. (2011). Material and energy recovery in integrated waste management systems. An evaluation based on life cycle assessment. Waste Management, 31(9-10), 2092-2101. DOI: https://doi.org/10.1016/j.wasman.2011.02.029

[3] Li, Y., Jin, Y., Borrion, A., \& Li, H. (2019). Current status of food waste generation and management in China. Bioresource technology, 273, 654-665. DOl: https://doi.org/10.1016/j.biortech.2018.10.083

[4] Kaza, S., Yao, L., Bhada-Tata, P., \& Van Woerden, F. (2018). What a waste 2.0: a global snapshot of solid waste management to 2050. The World Bank. DOl: https://doi.org/10.1596/978-1-4648-1329-0

[5] Alzate-Arias, S., Jaramillo-Duque, Á., Villada, F., \& Restrepo-Cuestas, B. (2018). Assessment of government incentives for energy from waste in Colombia. Sustainability, 10(4), 1294. DOI: https://doi. org/10.3390/su10041294

[6] Jeswani, H. K., \& Azapagic, A. (2016). Assessing the environmental sustainability of energy recovery from municipal solid waste in the UK. Waste Management, 50, 346-363. DOI: https://doi. org/10.1016/j.wasman.2016.02.010

[7] Scarlat, N., Motola, V., Dallemand, J. F., Monforti-Ferrario, F., \& Mofor, L. (2015). Evaluation of energy potential of municipal solid waste from African urban areas. Renewable and Sustainable Energy Reviews, 50, 1269-1286. DOI: https://doi.org/10.1016/j.rser.2015.05.067

[8] Singh, A., Tiwari, R., Chandrahas, \& Dutt, T. (2020). Augmentation of farmers' income in India through sustainable waste management techniques. Waste Management \& Research, 0734242X20953892. DOI: https://doi.org/10.1177/0734242X20953892

[9] Sapronova, Z., Sverguzova, S., \& Svyatchenko, A. (2019, December). Use of municipal vegetative waste as raw material for sorbent production. In IOP Conference Series: Materials Science and Engineering (Vol. 687, No. 6, p. 066061). IOP Publishing.

[10] Heredia-Guerrero, J. A., Heredia, A., Domínguez, E., Cingolani, R., Bayer, I. S., Athanassiou, A., \& Benítez, J. J. (2017). Cutin from agrowaste as a raw material for the production of bioplastics. Journal of experimental botany, 68(19), 5401-5410. DOI: https://doi. org/10.1093/jxb/erx272

[11] Rong, W. U., Shanjiang, L. I. U., \& Ying, D. U. (2016). Research Advances in Agricultural Reutilization of Urban-rural Organic Wastes. Agricultural Science \& Technology, 17(2).

[12] Liu, Y., Ni, Z., Kong, X., \& Liu, J. (2017). Greenhouse gas emissions from municipal solid waste with a high organic fraction under different management scenarios. Journal of Cleaner Production, 147, 451-457. DOI: https://doi.org/10.1016/j.jclepro.2017.01.135

[13] Hoornweg, D., \& Bhada-Tata, P. (2012). What a waste: a global review of solid waste management.

[14] Kumar, A., \& Samadder, S. R. (2020). Performance evaluation of anaerobic digestion technology for energy recovery from organic fraction of municipal solid waste: A review. Energy, 117253. DOl: https://doi.org/10.1016/j.energy.2020.117253

[15] Tufaner, F., \& Avşar, Y. (2014). Yenilenebilir Bir Enerji Kaynağ Olarak Organik Içeriği Yüksek Atıklardan Biyogaz Üretim Teknolojisi. Adıyaman Üniversitesi Bilim, Kültür ve Sanat Sempozyumu (ADYÜ-Sempozyum).

[16] Rayner, A. J., Briggs, J., Tremback, R., \& Clemmer, R. M. (2017). Design of an organic waste power plant coupling anaerobic digestion and solid oxide fuel cell technologies. Renewable and Sustainable Energy Reviews, 71, 563-571. DOI: https://doi.org/10.1016/j.rser.2016.12.084

[17] San Martin, D., Ramos, S., \& Zufía, J. (2016). Valorisation of food waste to produce new raw materials for animal feed. Food chemistry, 198, 68-74. DOl: https://doi.org/10.1016/j.foodchem.2015.11.035

[18] Mirabella, N., Castellani, V., \& Sala, S. (2014). Current options for the valorization of food manufacturing waste: a review. Journal of Cleaner Production, 65, 28-41. DOI: https://doi.org/10.1016/j.jclepro.2013.10.051

[19] Üstün, I , Koç, Y, Yağlı, H , Köse, Ö , Başar, M , Karakuş, C, Akgöl, $\mathrm{O}$, Koç, A . (2019). Determination of heat transfer coefficient and electromagnetic directional analysis of pomegranate seed . International Advanced Researches and Engineering Journal , 3 (2) , 98-104 . DOI: $10.35860 /$ iarej. 412270

[20] Başar, M. T. (2020). Organik atıkların geri kazanımı için mekanik, ısıl ve elektromanyetik özelliklerinin araştırılması (Master's thesis, İskenderun Teknik Üniversitesi/Mühendislik ve Fen Bilimleri Enstitüsü/Makine Mühendisliği Anabilim Dalı).

[21] Abdulkarim, Y. l., Deng, L., Altıntaş, O., Ünal, E., \& Karaaslan, M. (2019). Metamaterial absorber sensor design by incorporating swastika shaped resonator to determination of the liquid chemicals depending on electrical characteristics. Physica E: Low-dimensional Systems and Nanostructures, 114, 113593. DOI: https://doi. org/10.1016/j.physe.2019.113593

[22] Balçıkanlı, M. (2016). Alkalilerle aktive edilmiş çimentosuz cüruflu betonların mekanik ve geçirimlilik özellikleri ve üretim optimizasyonu (Master's thesis, İskenderun Teknik Üniversitesi/Mühendislik ve Fen Bilimleri Enstitüsü/Inş̧aat Mühendisliği Anabilim Dalı). 